\title{
Butterflies of the Bukit Timah Nature Reserve, Singapore, and its vicinity
}

\author{
S.K. Khew ${ }^{1} \&$ H. Tan ${ }^{2}$ \\ Lee Kong Chian Natural History Museum, 2 Conservatory Drive, \\ National University of Singapore, 117377 Singapore \\ khew.sin.khoon@cpgcorp.com.sg
}

\begin{abstract}
A survey of butterflies has been undertaken within the Bukit Timah Nature Reserve (BTNR), Singapore, and in the adjacent well-vegetated areas that form a buffer to BTNR, namely Hindhede Park, Singapore Quarry and the Dairy Farm Nature Park. Sampling was mainly though observations and photographic records along the transects in BTNR, and through baiting (mainly at Dairy Farm). More butterfly species (85) were recorded from the buffer areas, which have more open, sunnier secondary forest with more conspicuous food sources for adult butterflies, than there were from BTNR (63). Despite the high plant species richness at BTNR, the butterfly diversity observed within the forest transects was rather low. The greater butterfly diversity at Dairy Farm Nature Park is attributable in part to higher abundance of nectar sources (flowering trees and bushes, including many non-native plants growing along the forest edge and along open trails and footpaths). However, there are likely to be more species within BTNR, such as in the tree canopy, that were beyond the sampling scope of this survey.
\end{abstract}

Keywords. Biodiversity surveys, butterfly conservation, Lepidoptera, Rhopalocera.

\section{Introduction}

Bukit Timah Nature Reserve (BTNR) is one of the few remaining patches of primary rain forest left in Singapore. Information about the Nature Reserve and its history is provided by Chin et al. (1995) and by Lum \& Sharp (1996). Despite its relatively small size of about 163 ha, of which less than half is primary forest, it is home to a diverse range of flora and fauna. In a survey of the Central Catchment Nature Reserve and other parks across Singapore in the mid-1990s, a total of 236 species of butterflies were recorded (Khew \& Neo, 1997). A subsequent and more recent inventory of butterflies for the whole of Singapore puts the extant species at a total of 334 species (Jain et al., 2018).

Butterflies are a well-studied taxonomic group in Singapore and in the region (Corbet \& Pendlebury, 1992; Eliot, 2006; Fleming, 1991). As most species are readily identifiable in the field (Khew, 2010, 2015; Kirton, 2014; Tan \& Khew, 2012), they are an excellent group for monitoring environmental changes by making repeated site-specific surveys. Furthermore, the conservation status of many species has been determined (Khew, 2008), so that butterfly surveys can be interpreted in terms of conservation value. This is the first time that the butterfly diversity of BTNR has been 
surveyed and recorded over two consecutive years, and it is the second major survey of the nature reserve following that by Khew \& Neo (1997). The temporary closure of BTNR for upgrading and improvement works was an opportunity to carry out surveys without the weekend crowds and disturbance from the public. Although the survey of BTNR focused on five selected transects, further investigations were made in the adjacent areas surrounding BTNR.

\section{Materials and Methods}

Surveys were conducted along five trails, selected for their representation of primary, old secondary forest and maturing secondary forest within BTNR, as shown in Fig. 1. They were Jungle Fall Path and Seraya Loop (T1: primary forest), the main Summit Road (T2: primary forest), Catchment Path (T3: old secondary forest), South View Path (T4: old secondary forest) and Lasia Track (T5: maturing secondary forest). Survey dates are given in Appendix 1. The surveys along the five transects were based on visual observations and (when possible) photographic records of the butterfly species observed. The surveys were conducted mostly in the mornings except for two surveys that were done in the afternoon. A further series of surveys was conducted in the surrounding buffer areas to BTNR. These included two surveys of Dairy Farm Nature Park (DFNP) on 26 November and 17 December 2016, one survey of Singapore Quarry (SQ) on 18 February 2017 and one survey of Hindhede Quarry (HQ) on 2 July 2017. As these areas are adjacent and physically contiguous with BTNR, the presence/absence of mobile organisms like butterflies needs to be considered in the wider context so as to draw conclusions relevant to butterfly diversity in BTNR.

\section{Results}

\section{Butterfly diversity in BTNR}

During the series of eight field surveys conducted along the five transects within BTNR, a total of 63 species were recorded, out of the total of 334 species of butterflies that have been recorded in Singapore. All six of the locally-occurring butterfly families (Papilionidae, Pieridae, Nymphalidae, Riodinidae, Lycaenidae and Hesperiidae) were represented amongst the butterfly species observed. As the five transects were mainly within and surrounded by forest, and there was a general lack of flowering plants that butterflies visit to feed on nectar, it is not surprising that the species count was low. In four of the five transects, tall trees and thick foliage flanked both sides of the trail, limiting the amount of sunlight penetrating into the transects. Only the Summit Trail was reasonably broad. Given that these transects are within tall forest, it was quite expected that the species observed were mainly forest-dependent butterflies, of which the majority were shade-loving species that prefer forested areas. Species that are often found to forage in the forested understorey amongst damp leaf litter and on fallen fruits (e.g. from Ficus spp.) were also present. In some areas along 


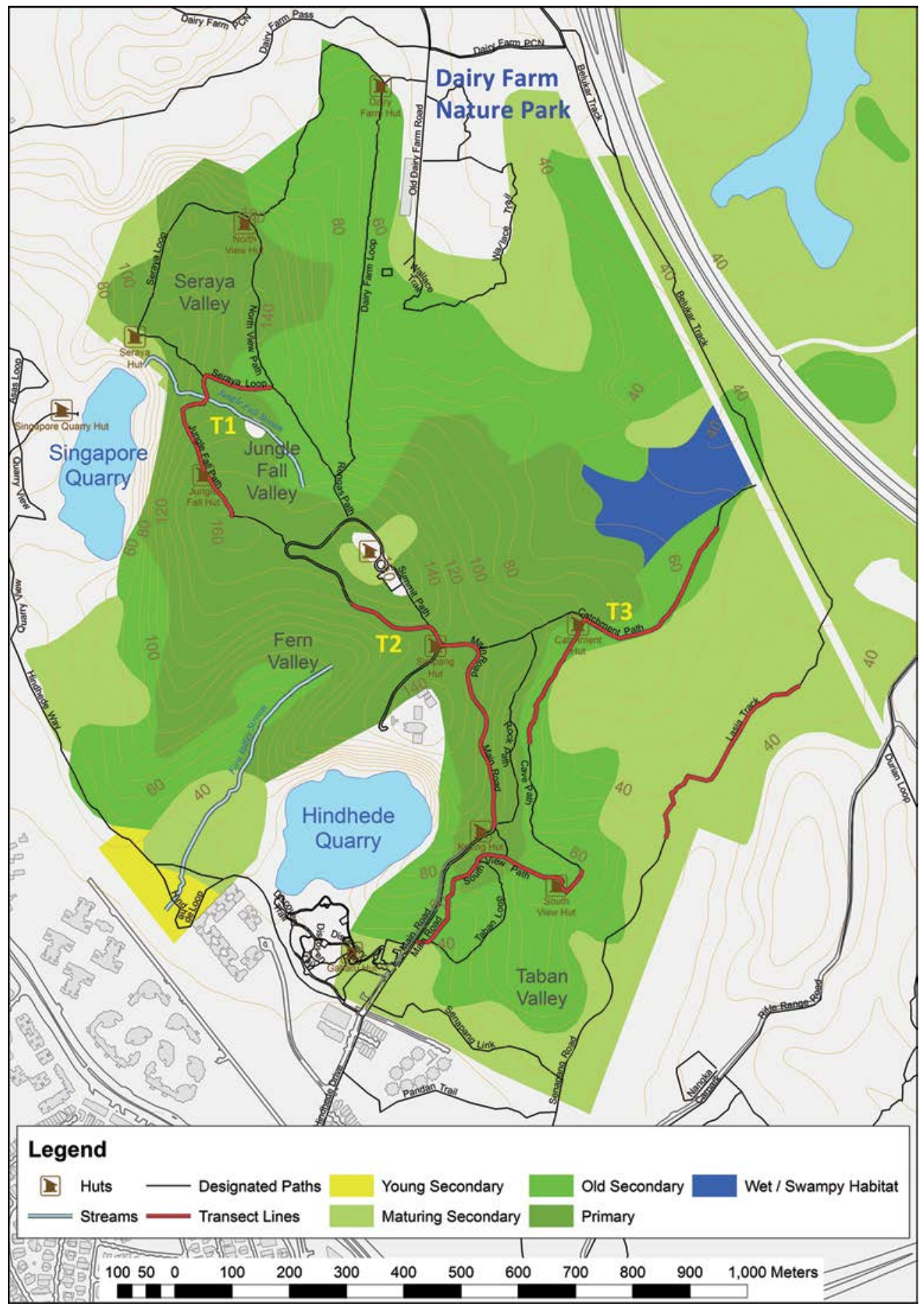

Fig. 1. Transects used to survey butterflies at Bukit Timah Nature Reserve, Singapore, and adjacent areas. (Source: NParks) 
the transects, the open sandy path also provided mud-puddling opportunities for a variety of butterfly species that are regularly seen to engage in this activity.

None of the butterfly species was found in all five transects. Out of 63 species, only four were found in all three vegetation zones, primary forest (T1 and/or T2), old secondary forest (T3 and/or T4) and maturing secondary forest (T5). Those four widely distributed species were Papilio polytes, Eurema sari, Gandaca harina and Elymnias hypermnestra. Not much should be read into this because, out of a possible maximum of 315 combinations $(63$ species $\times 5$ transects $=315)$ only 118 combinations were actually recorded (shown in Appendix 1 as numbers observed), and 67 of those (57\%) were observations of single individuals. In fact, out of the 63 species observed in BTNR during the survey period, 22 (35\%) were represented by a single sighting. This demonstrates an important feature of rain forest communities (many species, but few individuals of each one), highly relevant to conservation and sustainability of faunas, but it also means that chance played a big part in encounters, so much more survey effort would be required in order to detect faunal differences between the forest zones.

\section{Genera/Species of note in BTNR}

Whilst the butterfly species observed within BTNR were not unexpected, the following genera/species are worthy of a special commentary and mention:

\section{The Blue Helen, Papilio prexaspes prexaspes (C. \& R. Felder, 1865) (Fig. 2A)}

This species was a new discovery for Singapore when it was first recorded in the late 1990s. It is a fairly large butterfly, with a wingspan of about $90-100 \mathrm{~mm}$. It was observed at two of the transects in BTNR, T1 and T2 (both within primary forest), mainly within the forested understorey. The regular observation of this species in and around the broad neighbourhood of the central catchment forests confirms that it has established a viable and sustainable population in Singapore and can no longer be considered a seasonal migrant/vagrant. Its caterpillar host plants are likely to be either the same as, or related to, the plant species fed on by other butterfly species closely related to the Blue Helen. One of its known host plants, Maclurodendron porteri (Hook.f.) T.G.Hartley, is present at Jungle Fall Path, Jungle Fall stream and Cave Path; another, Zanthoxylum nitidum (Roxb.) DC., has never been reported from BTNR but other species of Rutaceae in BTNR include Clausena excavata Burm.f., Glycosmis chlorosperma (Blume) Spreng., Luvunga crassifolia Tanaka, and three species of Melicope J.R.Forst. \& G.Forst. (see Ho et al., 2019) and may help to support the continued survival of the Blue Helen in Singapore.

\section{The Chocolate Grass Yellow, Eurema sari sodalis (Moore, 1886) (Fig. 2B)}

Members of the genus Eurema (commonly referred to as "Grass Yellows") are found flying around the forest edges and along open paths in BTNR. Occasionally, a number of individuals have been observed mud-puddling together at damp sandy footpaths within BTNR. In the case of the Chocolate Grass Yellow, a group of 15 or more individuals was spotted puddling along the damp path along transect T5 (maturing secondary forest). 
3. The Magpie Crow, Euploea radamanthus radamanthus (Fabricius, 1793) (Fig. 2C) The Magpie Crow is not considered a common butterfly species in Singapore, although its distribution is widespread and individuals turn up at various localities across Singapore. However, the species has been consistently spotted (sometimes several individuals are seen together) near the base of the Summit Road near the BTNR Visitor Centre. This species has not been successfully bred in Singapore yet, and its caterpillar host plant is so far unknown. Its regular appearance near the BTNR Visitor Centre area may suggest that its caterpillar host plant grows in the vicinity and should be looked for.

4. The Malay Tailed Judy, Abisara savitri savitri (C. \& R. Felder, 1860) (Fig. 2D) The majority of the species of the Riodinidae family are shade-lovers and forestdependent. They rarely move out from the sanctuary of the shady forest understorey and the conservation of large patches of forest like the BTNR is important for the survival of such species of butterflies. The Malay Tailed Judy is a moderately rare butterfly species and can be found in habitats such as those in BTNR.

\section{The Quaker, Neopithecops zalmora zalmora (Butler, 1870) (Fig. 2E)}

This diminutive butterfly is considered moderately rare in Singapore but is regularly spotted within BTNR and the surrounding areas. It was spotted at three out of the five transects during the surveys (one in primary forest and two in old secondary forest), usually fluttering restlessly in the shady forested understorey amongst the low shrubbery. Its caterpillar host plant in Singapore is Glycosmis chlorosperma (Blume) Spreng. and is likely to be a plant that is easily found in BTNR.

\section{Various Arhopala spp. (Boisduval, 1832)}

The genus Arhopala comprises a number of shade-loving forest-dependent species that prefer habitats like those in BTNR. This is an important genus that requires further studies to establish the diversity of species that occur in Singapore. Their cryptic appearance makes field identification challenging and over the last two decades, more species have been discovered or re-discovered through opportunistic breeding of eggs and caterpillars found on a wide variety of host plants in the nature reserves. During the survey, one of the species added to the Singapore Butterfly Checklist was the Bright Oakblue Arhopala sublustris ridleyi (Corbet, 1941) (Fig. 2F). It was surprisingly common along the Summit Road (T2) and a total of no fewer than eight individuals were recorded over only two surveys at T1 and T2. When observed in numbers, the Arhopala spp. are usually in the vicinity of the species' caterpillar host plants. That the Bright Oakblue was seen along the main road leading up to Bukit Timah summit strongly suggests that its caterpillar host plant is not far from this area.

\section{The Banded Royal, Rachana jalindra burbona (Hewitson, 1878) (Fig. 3A)}

This very rare Lycaenid has been observed no more than a dozen times in Singapore over the past 10 years. During the survey at T2, a single male Banded Royal was recorded near the BTNR summit. In butterfly behaviour, a phenomenon known as "hill-topping" is a well-documented butterfly activity. Males in particular, will choose 
a favourite perch and patrol the area for eligible females. BTNR's summit, being the highest peak in Singapore, is probably an ideal place for such butterfly activity, and further observations for hill-topping behaviour should be made at the summit in future.

8. The Fulvous Pied Flat, Pseudocoladenia dan dhyana (Fruhstorfer, 1909) (Fig. 3B) The Fulvous Pied Flat was first recorded in the open forest edge along Quarry View and Asas Loop in the early 2000s (ButterflyCircle, 2008). First discovered in the BTNR area, the Fulvous Pied Flat has, time and again, appeared at and around the forests in BTNR. It was spotted at T5 (maturing secondary forest) in an open area where its caterpillar host plant, Cyathula prostrata (L.) Blume (Amaranthaceae), a low ground cover creeper, can be found. Again, the caterpillar host plant is key to the survival of this species.

9. The Giant Redeye Gangara thyrsis thyrsis (Fabricius, 1775) (Fig. 3C \& D)

This very rare Hesperiid is a resident of deep shaded forest habitats, particularly where its caterpillar host plant, Eugeissona tristis or bertam palm grows. At transect T1, a caterpillar of this species was found feeding on the leaves of a palm, presumably Oncosperma horridum, as the bertam palm has never been recorded from Singapore (see Ho et al., 2019). It was collected, but unfortunately did not survive to adulthood. The combination of the occurrence of a viable alternative host plant, the habitat and shaded forest understorey at BTNR is key to the continued survival of this species in Singapore.

\section{Butterfly diversity in areas surrounding BTNR}

Further observations were recorded from three areas beyond the Nature Reserve and compared with the data collected for the five transects at BTNR. The Dairy Farm Nature Park and Singapore Quarry environments are generally more open and have more forest-edge habitats with a markedly higher diversity of flowering plants and 'wild flowers' that provide more food sources for butterflies. The Hindhede Park habitat is more similar to the habitats within BTNR. The number of butterfly species recorded over eight surveys at BTNR was 63 whilst the total number of species found in the three surrounding areas was 85 . That these buffer areas to BTNR play an important role in providing food sources for the adult butterflies is evident in the higher diversity of species, despite the fewer surveys conducted.

Of the three surrounding areas, the best butterfly diversity recorded was from Dairy Farm Nature Park. The availability of nectar sources and other types of food sources is key to the higher diversity. Over the years, nature photography groups have recorded a high number of butterfly species at Dairy Farm Nature Park. In particular, when the trees planted near the Wallace Education Centre - Syzygium spp. and Antidesma velutinosum - are in flower, there is an amazing range of butterfly species attracted to the flowers of these trees. 

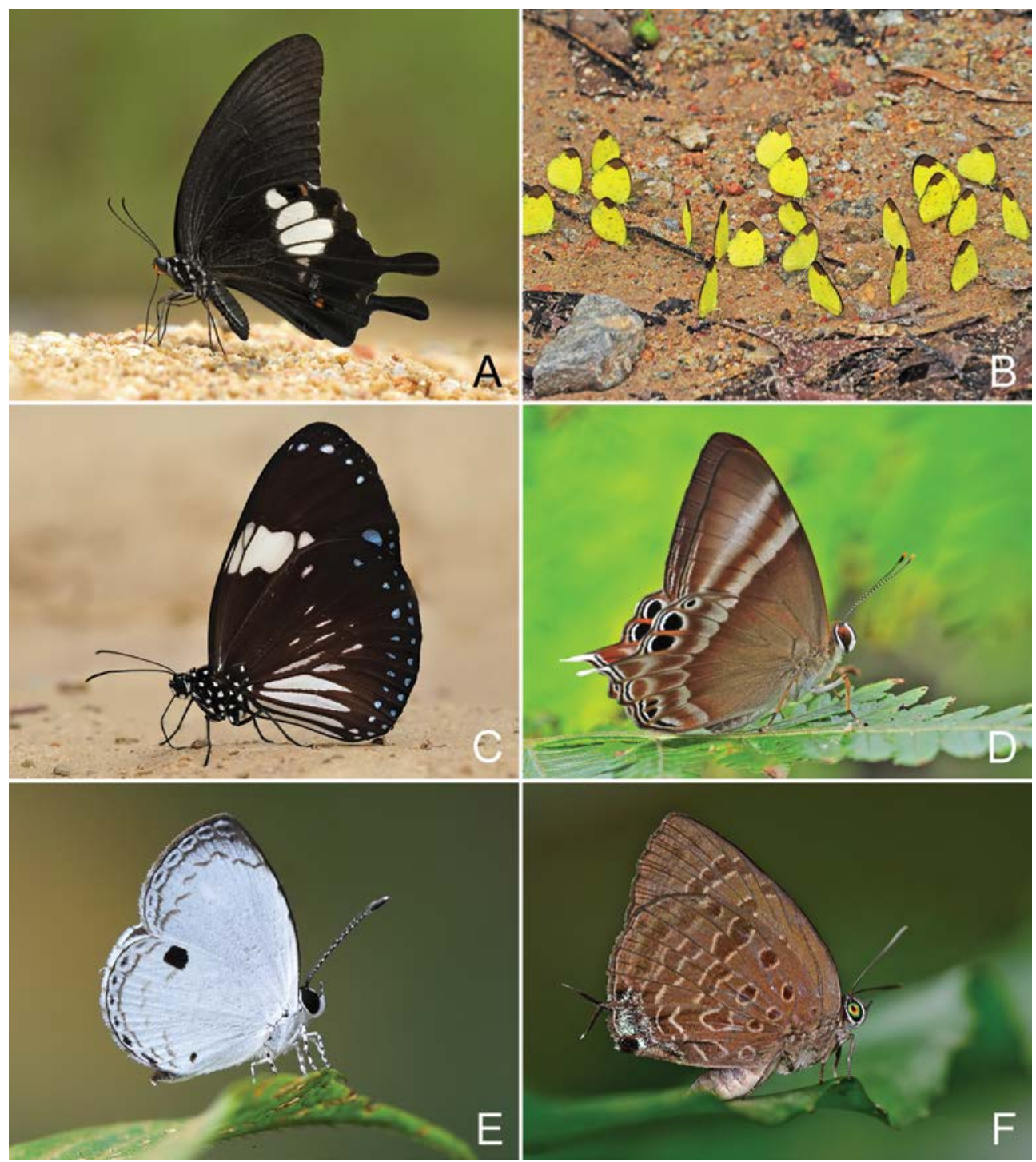

Fig. 2. A. Blue Helen, Papilio prexaspes prexaspes. B. Chocolate Grass Yellow, Eurema sari sodalist. C. Magpie Crow, Euploea radamanthus radamanthus. D. Malay Tailed Judy, Abisara savitri savitri. E. Quaker, Neopithecops zalmora zalmora. F. Bright Oakblue, Arhopala sublustris ridleyi. (Photos: S.K. Khew)

\section{Similarities and Differences}

Table 1 shows the number of butterfly species that were found only in BTNR, those found only in the three abutting areas of Dairy Farm, Singapore Quarry and Hindhede Park, and those that were common to all areas. They are broken down according to family and subfamily. Of the 63 species recorded within BTNR, nearly half (27) were found only there. Not surprisingly, many of those are from the Nymphalidae, which is 

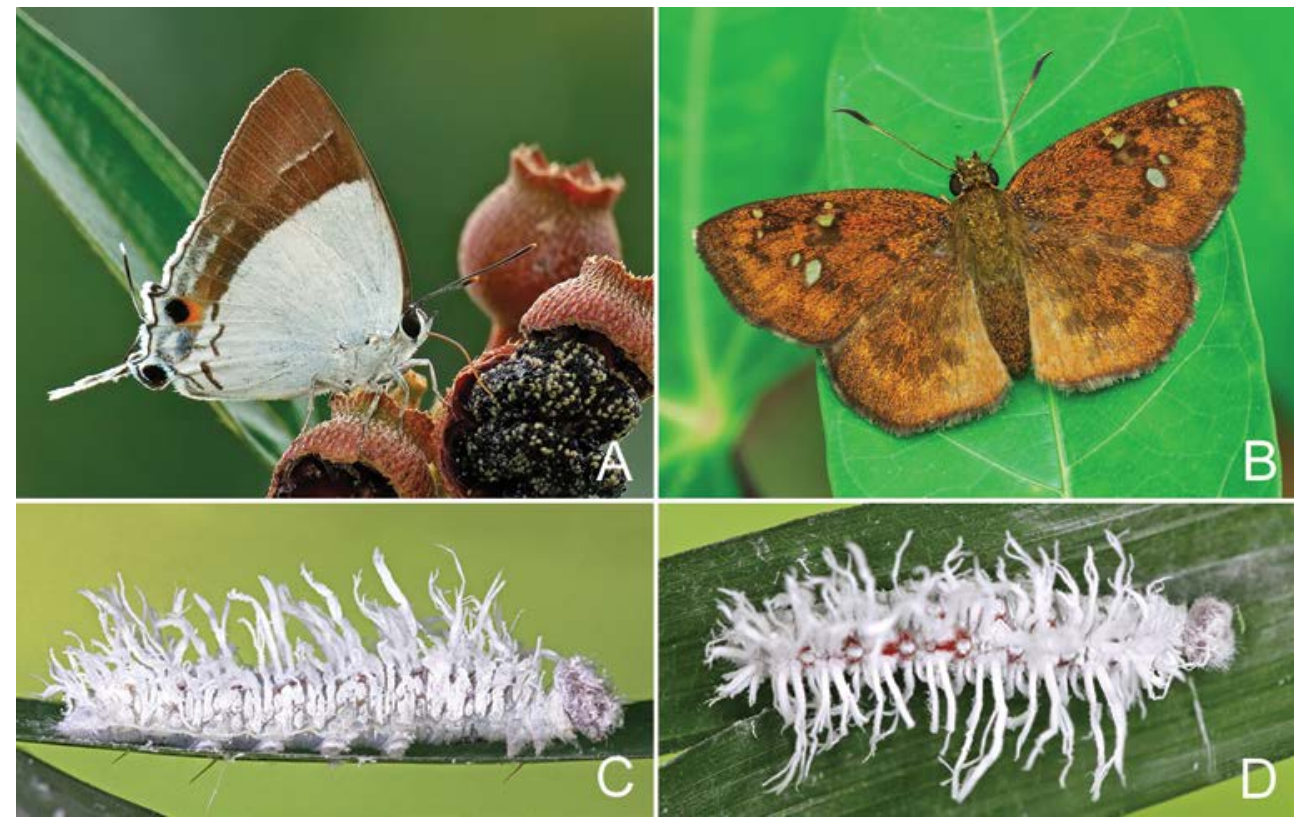

Fig. 3. A. Banded Royal, Rachana jalindra burbona. B. Fulvous Pied Flat, Pseudocoladenia dan dhyana. C \& D. Caterpillar of Giant Redeye, Gangara thyrsis thyrsis. (Photos: A \& B, S.K. Khew; C \& D, H. Tan)

known to contain many shade-loving forms, but they also included eight Lycaenidae and a few Hesperiidae. Of the 85 species recorded only in the adjacent parks, 49 $(58 \%)$ were not found within the Nature Reserve; they included large numbers of Nymphalidae, Lycaenidae and Hesperiidae, and a good number of Papilionidae as well. Most of the Pieridae (seven out of ten species) were shared.

Out of the 112 species recorded in total (Appendix 1), 56\% (63 species) were found in BTNR, and $76 \%$ ( 85 species) were found in one or more of the adjacent parks. Finally, 36 species (32\%) were held in common between BTNR and the adjacent parks. The overall total of 112 species is just one-third of the total extant butterfly fauna of 334 species in Singapore (Jain et al., 2018).

\section{Discussion}

\section{Butterflies in BTNR}

Whilst the diversity of butterflies within BTNR is relatively low, this may be because many of the species observed along the transects are those that prefer shaded forest habitats. The relatively low abundance of free-flowering shrubs in the shaded understorey, compared to the forest edge, may be one of the factors for lower butterfly diversity and abundance. However, there are likely to be more species within BTNR that are canopy dwellers, beyond the scope of this survey. 
Table 1. The numbers of species of butterflies of each family and subfamily, detected in Bukit Timah Nature Reserve or the immediately adjacent parks, or in both.

Abbreviations: BTNR, Bukit Timah Nature Reserve. DFNP, Dairy Farm Nature Park. HP, Hindhede Park. SQ, Singapore Quarry.

\begin{tabular}{|c|c|c|c|c|}
\hline Family / Subfamily & $\begin{array}{l}\text { Detected } \\
\text { only within } \\
\text { BTNR }\end{array}$ & $\begin{array}{l}\text { Detected only } \\
\text { within } \\
\text { DFNP/SQ/HP }\end{array}$ & $\begin{array}{l}\text { Shared by BTNR } \\
\text { and } \\
\text { DFNP/SQ/HP }\end{array}$ & $\begin{array}{l}\text { Total } \\
\text { recorded } \\
\text { during } \\
\text { surveys }\end{array}$ \\
\hline Papilionidae & 1 & 7 & 4 & 12 \\
\hline Pieridae & 1 & 2 & 7 & 10 \\
\hline Pierinae & & & 3 & 3 \\
\hline Coliadinae & 1 & 2 & 4 & 7 \\
\hline Nymphalidae & 14 & 11 & 12 & 37 \\
\hline Danaiinae & 2 & 2 & & 4 \\
\hline Satyrinae & 2 & 2 & 4 & 8 \\
\hline Heliconiinae & 1 & 1 & 2 & 4 \\
\hline Nymphalinae & & 3 & 3 & 6 \\
\hline Limenitidinae & 8 & 2 & 3 & 13 \\
\hline Apaturinae & 1 & & & 1 \\
\hline Charaxinae & & 1 & & 1 \\
\hline Riodinidae & & 2 & 1 & 3 \\
\hline Lycaenidae & 8 & 13 & 8 & 29 \\
\hline Miletinae & & 2 & 1 & 3 \\
\hline Curetinae & & 1 & & 1 \\
\hline Polyommatinae & & 7 & 5 & 12 \\
\hline Theclinae & 8 & 3 & 2 & 13 \\
\hline Hesperiidae & 3 & 14 & 4 & 21 \\
\hline Coeliadinae & & 3 & & 3 \\
\hline Pyrginae & 1 & 4 & 1 & 6 \\
\hline Hesperiinae & 2 & 7 & 3 & 12 \\
\hline TOTAL & 27 & 49 & 36 & 112 \\
\hline
\end{tabular}


It is known that there is a close correlation between the diversity of plants and the diversity of butterflies. This is because the caterpillars of butterflies are very particular about the host plants that they feed on. Quite a number of butterfly species are known to feed on a host plant that is unique to that butterfly species. It is therefore important that a comprehensive inventory of the caterpillar host plants is continuously updated for BTNR as new information becomes available. Should a host plant be lost or become extinct, there is a potential loss of the related butterfly species whose caterpillar requires that host plant to survive.

BTNR may be a source area where many butterfly species live out their early stages before they eclose. Upon eclosion the adult butterfly then may leave the sanctuary of the forests to forage for food at nectar sources that are beyond the boundaries of BTNR.

It is difficult to draw firm conclusions about gains or losses in the butterfly fauna of BTNR because the survey 20 years ago covered BTNR and the Central Catchment Nature Reserve (CCNR) together. The arrival in Singapore of the Blue Helen and the Bright Oakblue have been described above. However, the present survey provides a firm footing for future surveys specific to BTNR and to the adjacent parks.

Butterflies in areas immediately adjacent to BTNR

The results of the survey in the three areas immediately adjacent to BTNR shows the importance of these open buffer zones in supporting the survival of butterflies. Dairy Farm Nature Park in particular has greater availability of herbaceous flowering plants and the more open, sunnier forest edges promote a richer butterfly diversity. The cultivation of flowering trees like Syzygium zeylanicum (L.) DC., Syzygium lineatum (DC.) Merr. \& L.M.Perry, Antidesma velutinosum Blume, and Calliandra haematocephala Hassk. has attracted a wide variety of butterfly species when these plants are in bloom. The availability of flowering shrubs like Leea indica (Burm.f.) Merr. and wild flowers like Asystasia gangetica (L.) T.Anderson in these open sunny areas also provide a good range of nectar sources for different species of butterflies. The creeper, Smilax setosa Miq., though native to Singapore, sometimes grows profusely at forest edges and is a caterpillar host plant for two forestdependent species - the Branded Imperial (Eooxylides tharis distanti) and the Yamfly (Loxura atymus fuconius).

\section{Conservation strategies}

\section{Conservation of BTNR}

The relatively low diversity of nectar sources within BTNR due to the heavily forested and shaded understorey habitats may be a contributing factor for the lower species richness in the surveys along the selected transects. However, the presence of certain butterfly species that are forest dependent for their caterpillar host plants, like the Blue Helen, Bright Oakblue (and other rarer Arhopala spp.), Magpie Crow, Giant Redeye, Fulvous Pied Flat and several other Lycaenidae, strongly suggests that the plant diversity at BTNR is critical to the survival of some of these butterflies. Hence the conservation and protection of the forest habitats is imperative to the continued sustainability of the population of these butterfly species in Singapore. The continued 
loss of their caterpillar host plants and habitat disturbance may reduce the size of the population of certain species to below a threshold level that could potentially cause the extirpation of these species altogether.

2. Maintaining healthy diversity of nectar and other food sources in buffer areas in adjacent parks

The results of the surveys in the buffer parks outside BTNR show that there is higher butterfly diversity, primarily due to the greater availability of flowering trees and shrubs with more open, sunnier edges that promote the growth of flowering low growing ground-cover plants and wild flowers. Whilst the plant diversity in the BTNR Core Area may provide the much-needed caterpillar host plants for some butterfly species, the availability of food sources for the adult butterflies must not be overlooked. This is where nature areas like Dairy Farm Nature Park, Singapore Quarry and Hindhede Park play an important role in sustaining butterfly populations with judicious planting of nectar sources for the butterflies.

3. Connecting BTNR and adjacent parks to other green spaces via park connectors and natureways

The Central Catchment Nature Reserves, BTNR and other major nature parks form a major catchment of plants which support the early stages of many butterfly species. Many of these forest plants are not found outside these nature reserves and are critical to the survival of many butterfly species. However, just as important, is the availability of food sources that include nectar-producing (flowering) plants, overripe fruits, tree sap and others that the adult butterflies depend on. Being aerial creatures, butterflies can be encouraged to forage for food at other locations that feature their food sources. This is where Singapore's urban green connectors come into play as a network of links that can connect the nature reserves to the regional parks and gardens in Singapore. If these green links are designed and managed to be 'butterfly-friendly', they will facilitate the movement of butterflies across different habitats to other food sources.

\section{Judicious management of non-native vegetation}

In general, non-forest or non-native vegetation is often considered to have limited conservation value in Singapore. However, for butterflies, many of these plants that are often classified as 'weeds' are as important for their survival as the rare dipterocarps in our nature reserves. An example is Passiflora foetida L., a caterpillar host plant for two species of butterflies that are new to Singapore, the Tawny Coster (Acraea terpsicore) and Leopard Lacewing (Cethosia cyane).

\section{Conclusion}

The BTNR survey for butterflies has yielded some interesting information about the importance of the forest plant diversity and habitat that support forest-dependent butterflies. However, whilst BTNR is vital to the survival of a number of butterfly species, adjacent parks and gardens provide the much-needed food sources for adult 
butterflies in the form of flowering and fruit plants from which these butterflies can obtain their sugary diet. The cultivated flora found in our urban parks and gardens are also good sources of food for butterflies and can be found forming a network of links between the nature reserves and public parks throughout Singapore.

ACKNOWLEDGEMENTS. We thank the National Parks Board, Singapore for providing permits for study of butterflies at BTNR vicinity. We are grateful to the members of ButterflyCircle, Singapore, in particular the late Sunny Chir, and also Chng Chuen Kiong, Loke Peng Fai, Simon Sng and Huang Caijin for their help in conducting the surveys and photography of butterflies.

\section{References}

ButterflyCircle (2008). Butterflies of Singapore: Life History of the Fulvous Pied Flat. www. butterflycircle.blogspot.com/2008/12/life-history-of-fulvous-pied-flat.html.

Corbet, A.S. \& Pendlebury, H.M. (1992). The Butterflies of the Malay Peninsula, $4^{\text {th }}$ ed., revised by Eliot, J.N. Kuala Lumpur, Malaysia: Malayan Nature Society.

Chin, S.C., Corlett, R.T., Wee, Y.C. and Geh, S.M. (eds). (1995). Gard. Bull. Singapore (Suppl. 3): 1-167.

Eliot, J.N. (2006). Updating the butterflies of the Malay Peninsula. Malayan Nat. J. 59(1): $1-49$.

Fleming, W.A. (1991). Butterflies of West Malaysia and Singapore, $2^{\text {nd }}$ ed. Kuala Lumpur: Longmans Malaysia.

Ho, B.C., Lua, H.K., Bazilah Ibrahim, Yeo, R.S.W., Athen, P., Leong, P.K.F., Ali Ibrahim, Koh, S.L., Hassan Ibrahim, Lindsay, S., Chin, L.L., Seah, W.W. \& Middleton, D.J. (2019). The plant diversity in Bukit Timah Nature Reserve, Singapore. Gard. Bull. Singapore 71 (Suppl. 1): xx-Xx.

Jain, A., Khew, S.K., Gan, C.W. \& Webb, E.L. (2018). Butterfly extirpations, discoveries and rediscoveries in Singapore over 28 years. Raffles B. Zool. 66: 217-257.

Khew, S.K. (2008). Checklist of Singapore Butterflies. In: Davison G.W.H., Ng P.K.L. \& Ho, H.C. (eds) The Singapore Red Data Book: Threatened Plants and Animals of Singapore, $2^{\text {nd }}$ ed., pp. 250-258. Singapore: The Nature Society (Singapore).

Khew, S.K. (2010). A Field Guide to the Butterflies of Singapore. Singapore: Ink on Paper Communications Pte Ltd.

Khew, S.K. (2015). A Field Guide to the Butterflies of Singapore, $2^{\text {nd }}$ ed. Singapore: Ink on Paper Communications Pte Ltd.

Khew, S.K. \& Neo, S.S.H. (1997). Butterfly Biodiversity in Singapore with Particular Reference to the Central Catchment Nature Reserve. Proceedings of the Nature Reserves Survey Seminar. Gard. Bull. Singapore 49: 273-296.

Kirton, L.G. (2014). A Naturalist's Guide to the Butterflies of Peninsular Malaysia, Singapore and Thailand. Oxford: John Beaufoy Publishing.

Lum, S. \& Sharp, I. (eds) (1996). A View from the Summit: The Story of Bukit Timah Nature Reserve. Singapore: Nanyang Technological University and the National University of Singapore, in conjunction with the National Parks Board.

Tan H. \& Khew S.K. (2012). Caterpillars of Singapore's Butterflies. Singapore: National Parks Board. 


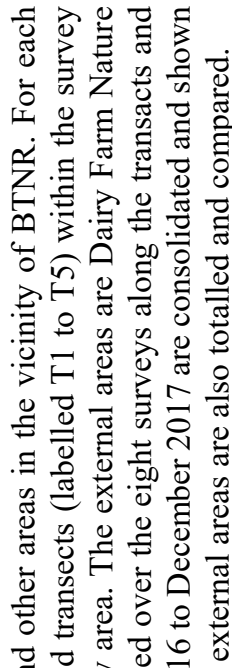

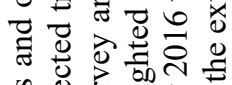

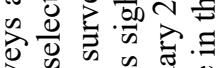

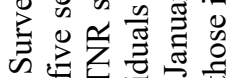

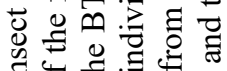

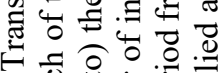

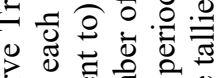

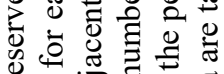

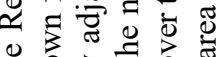
을 है के

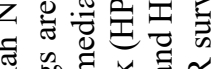
때

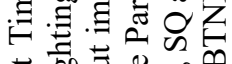

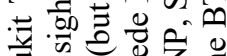

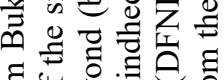

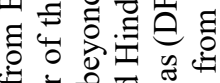

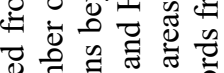

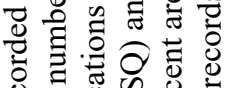

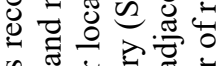
क त

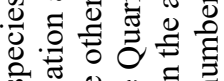
की तु

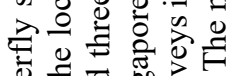
可

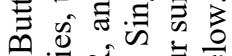

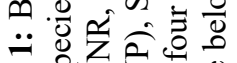
की 는.

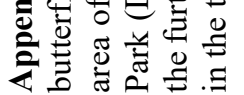

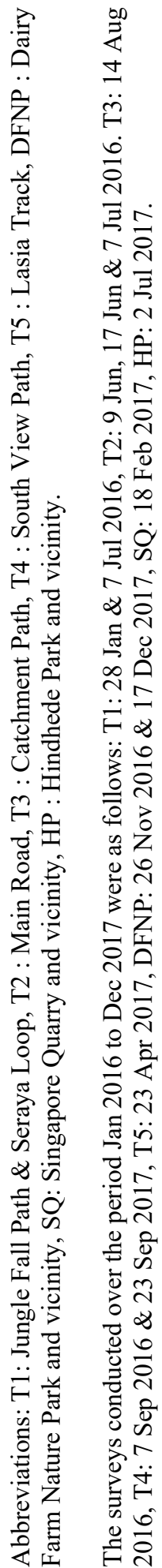

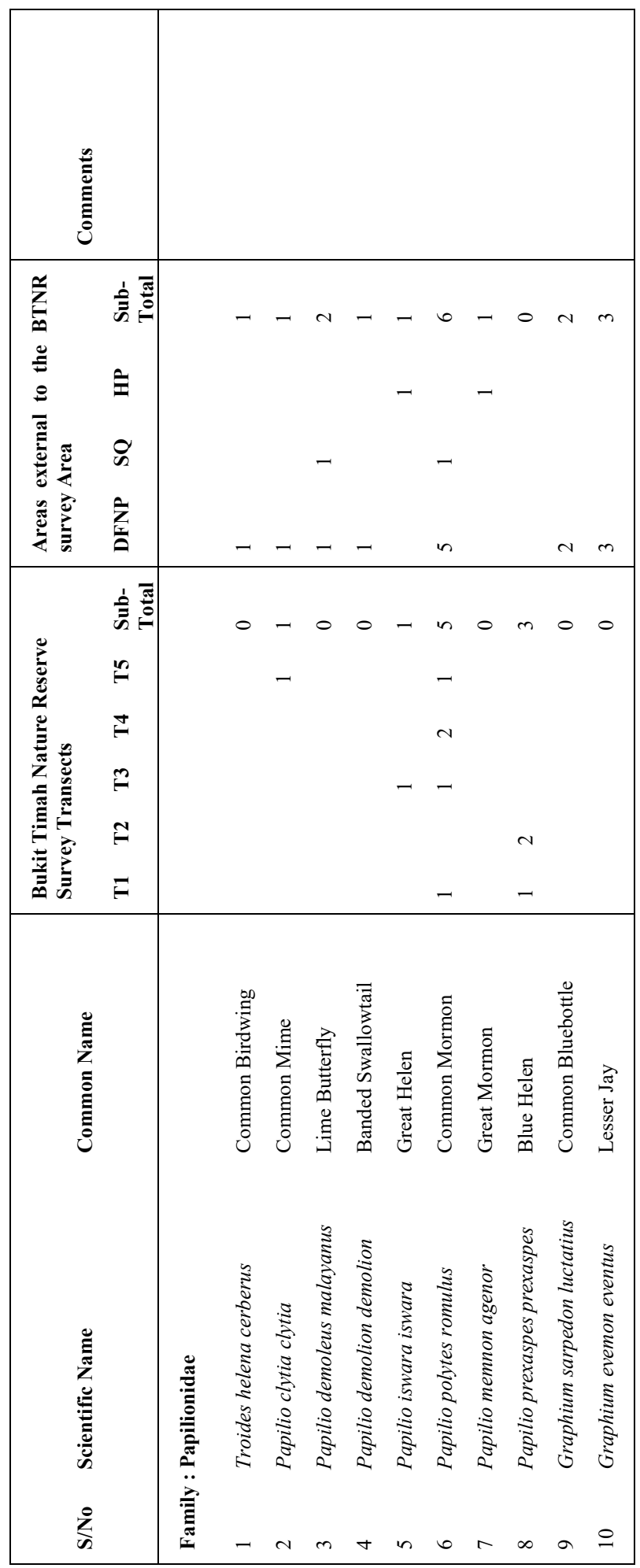




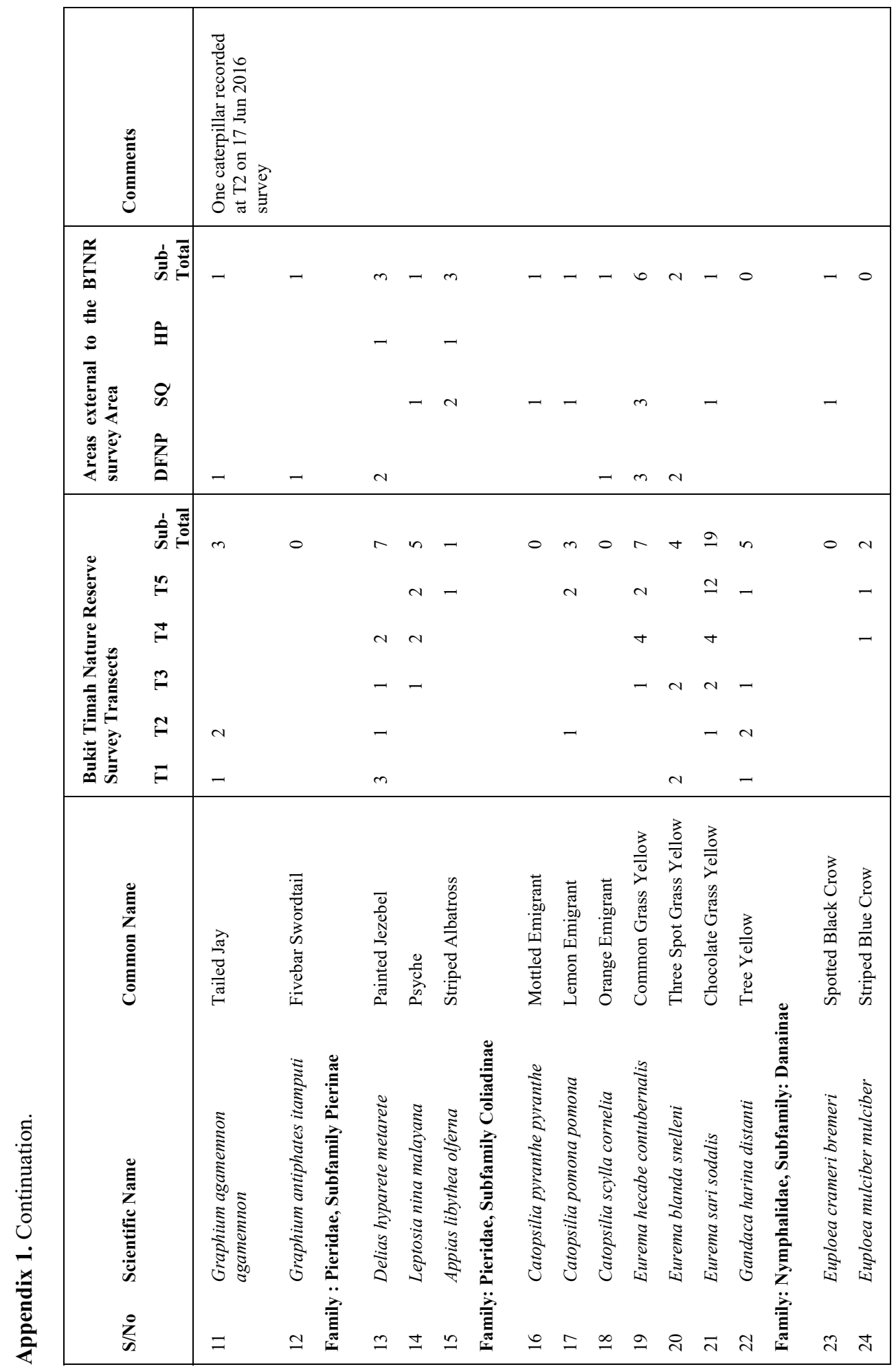




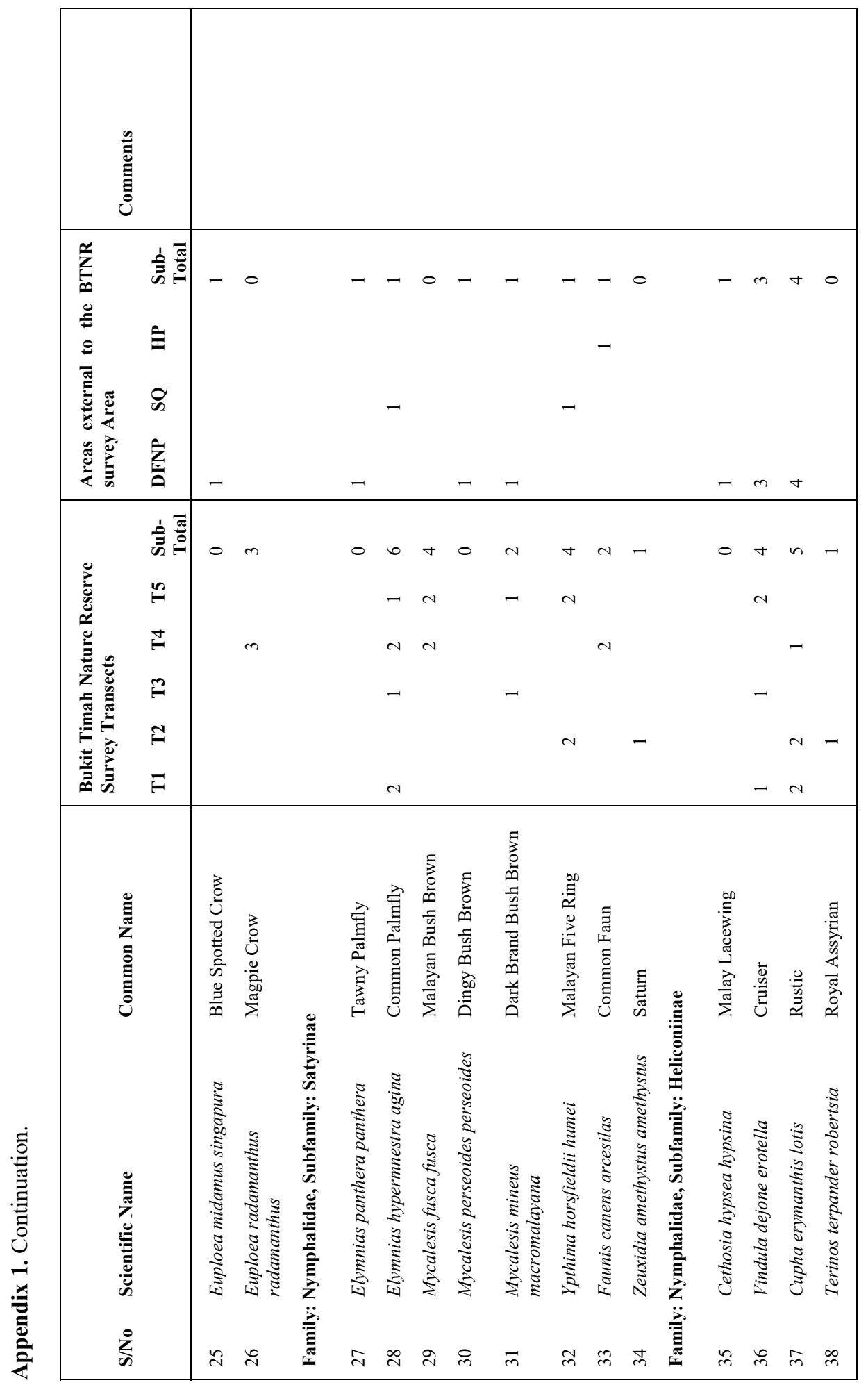




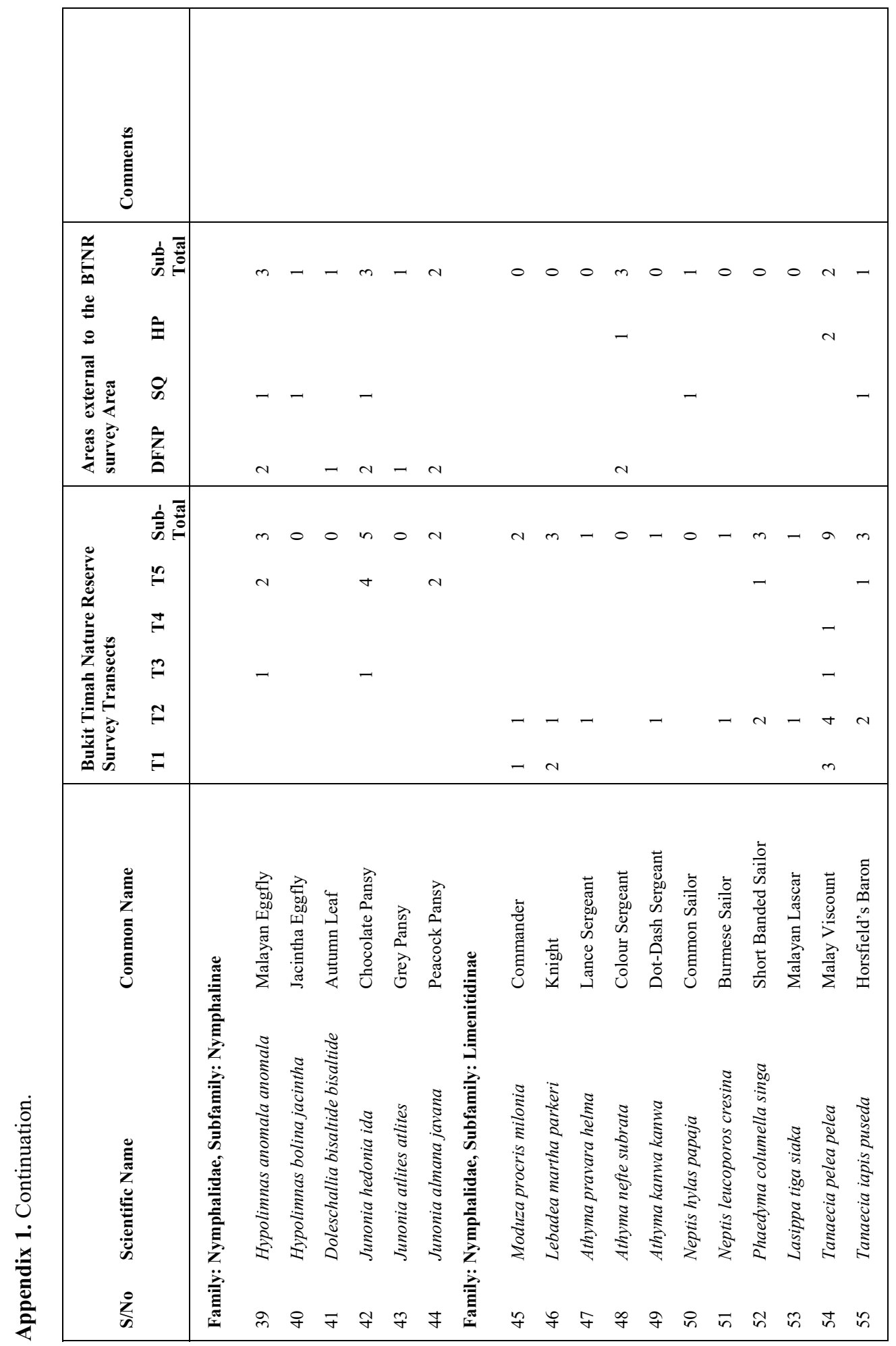




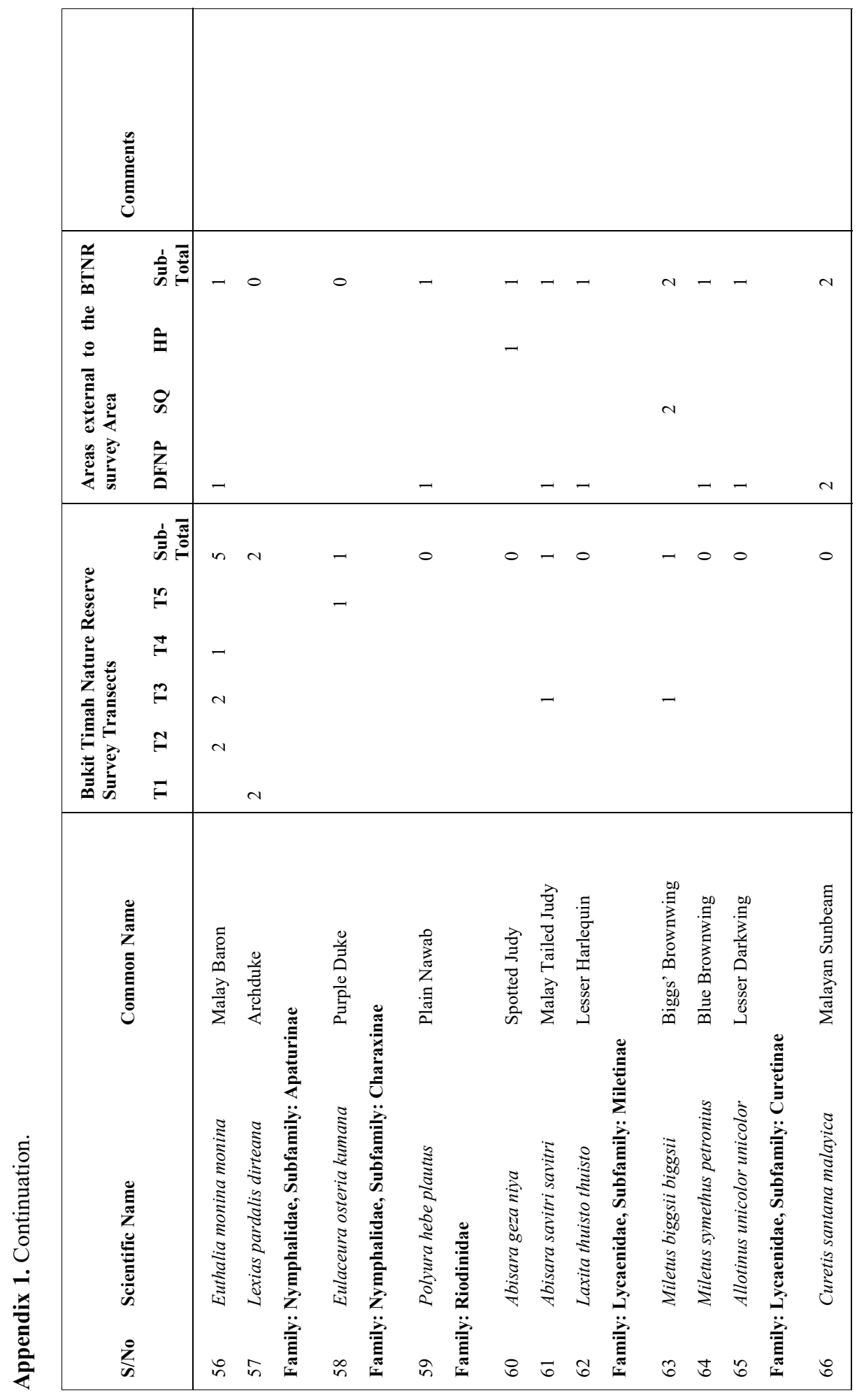




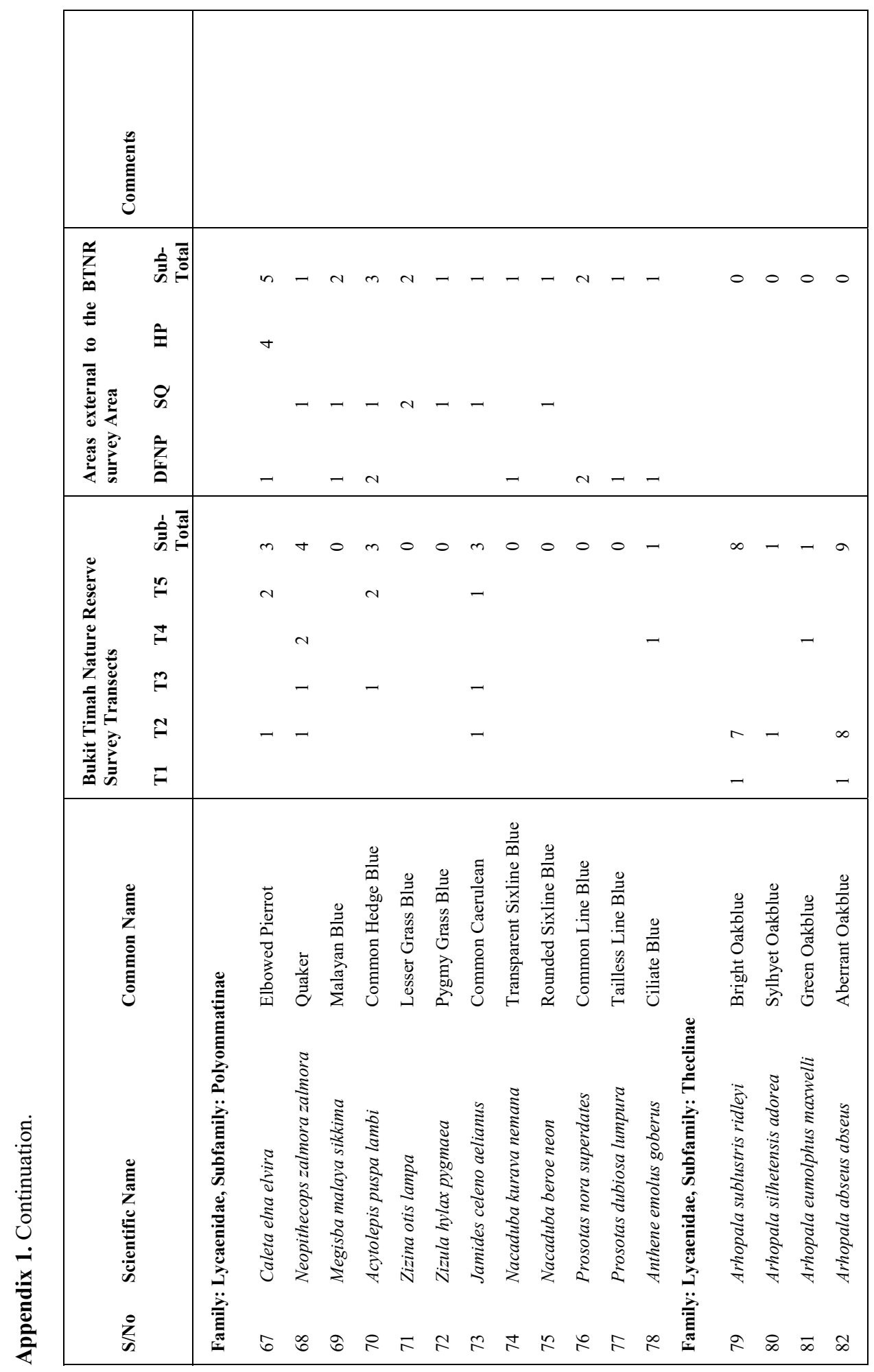




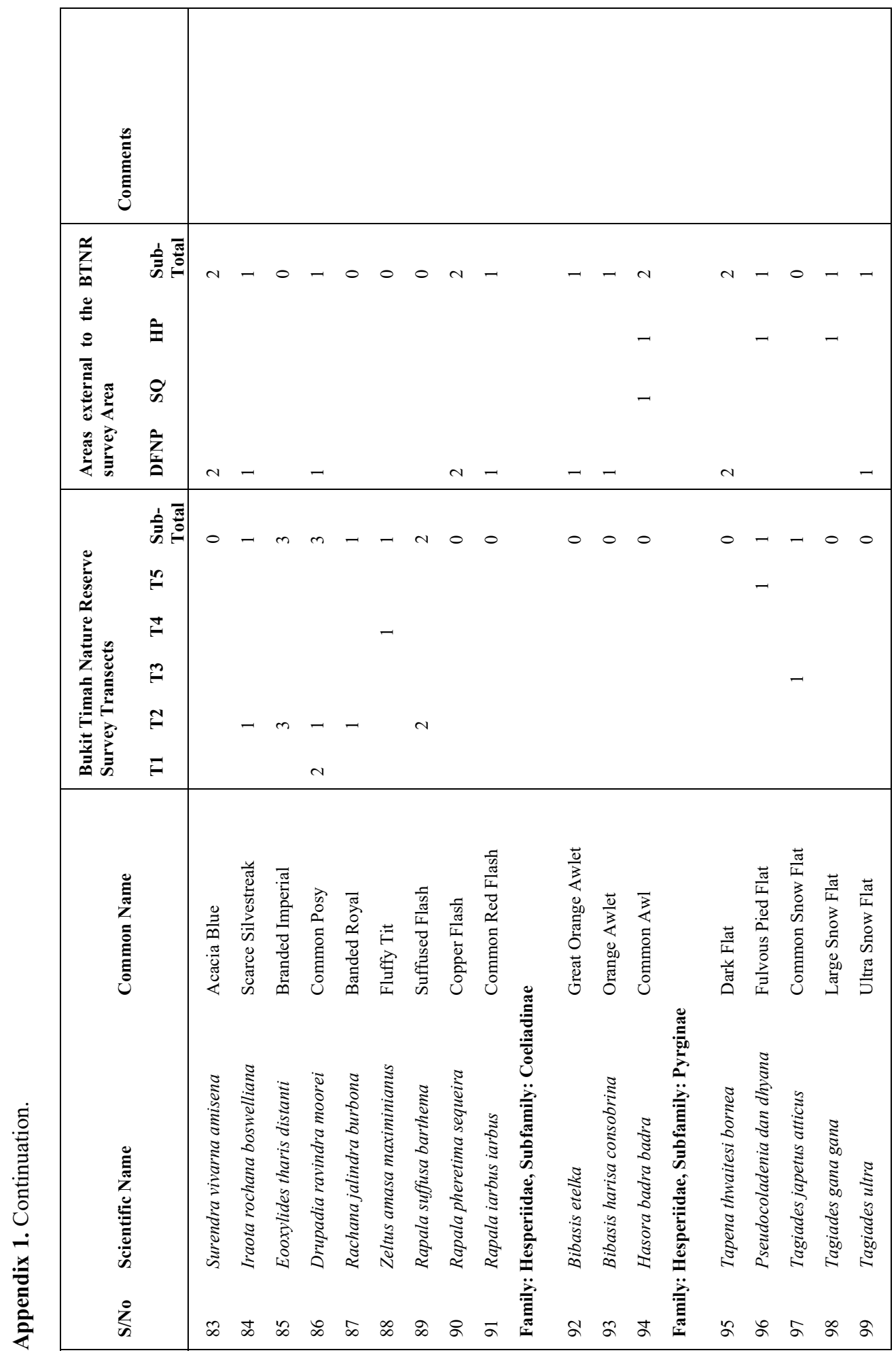




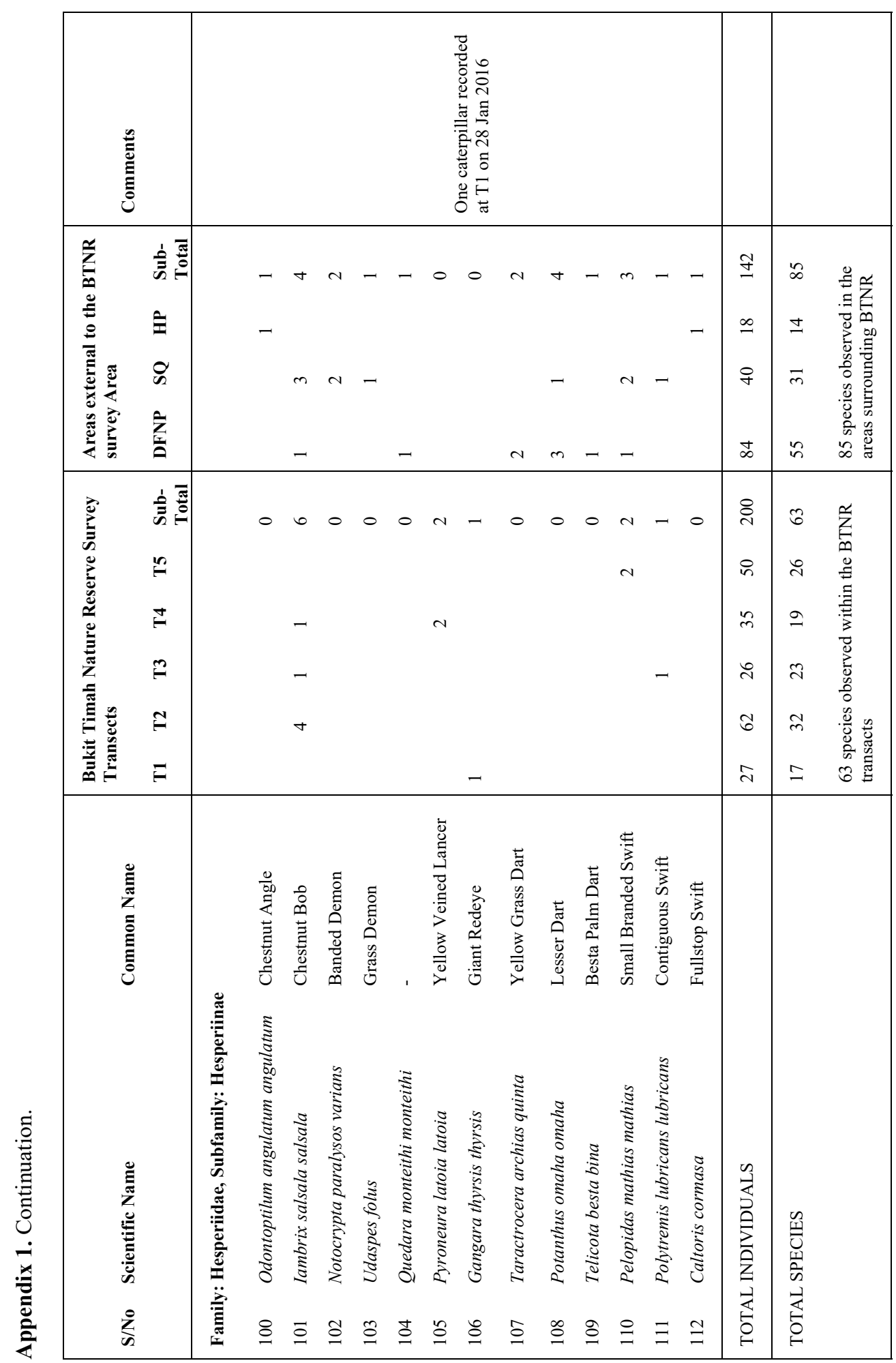

